Keywords:

Actinide, Precipitation

Sodium oxalate, Sorption

\title{
Evaluation of the Effects of Tank 50H Solids on Dissolved Uranium, Plutonium and Neptunium.
}

Authors: L. N. Oji and D. T. Hobbs

Publication Date: February 28, 2003

Westinghouse Savannah River Company Savannah River Site

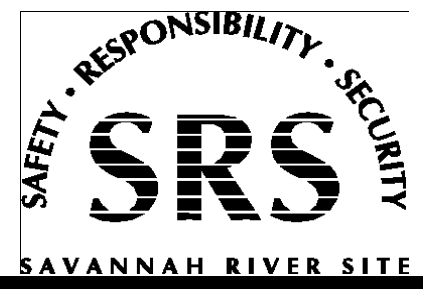


This page intentionally left blank 
This document was prepared in conjunction with work accomplished under Contract No. DE-AC09-96SR18500 with the U. S. Department of Energy.

\section{DISCLAIMER}

This report was prepared as an account of work sponsored by an agency of the United States Government. Neither the United States Government nor any agency thereof, nor any of their employees, makes any warranty, express or implied, or assumes any legal liability or responsibility for the accuracy, completeness, or usefulness of any information, apparatus, product or process disclosed, or represents that its use would not infringe privately owned rights. Reference herein to any specific commercial product, process or service by trade name, trademark, manufacturer, or otherwise does not necessarily constitute or imply its endorsement, recommendation, or favoring by the United States Government or any agency thereof. The views and opinions of authors expressed herein do not necessarily state or reflect those of the United States Government or any agency thereof.

This report has been reproduced directly from the best available copy.

Available for sale to the public, in paper, from: U.S. Department of Commerce, National Technical Information Service, 5285 Port Royal Road, Springfield, VA 22161, phone: (800) 553-6847, fax: (703) 605-6900

email: orders@ntis.fedworld.gov

online ordering: http://www.ntis.gov/help/index.asp

Available electronically at http://www.osti.gov/bridge

Available for a processing fee to U.S. Department of Energy and its contractors, in paper, from: U.S. Department of Energy, Office of Scientific and Technical Information, P.O. Box 62, Oak Ridge, TN 37831-0062,

phone: (865)576-8401,

fax: (865)576-5728

email: $\underline{\text { reports@ adonis.osti.gov }}$ 


\section{SUMMARY}

We examined the effects of contacting a simulated salt solution spiked with uranium, plutonium and neptunium with Tank $50 \mathrm{H}$ solids. The composite Tank $50 \mathrm{H}$ solids used in this study contained $0.365 \pm 0.030 \mathrm{mg}$ uranium per gram and $350 \pm 9.0 \mathrm{mg}$ oxalate anion per gram of Tank $50 \mathrm{H}$ solids. General findings from the study included the following:

- There is no evidence for interaction between Tank $50 \mathrm{H}$ solids and uranium from the spiked salt solution.

-Lack of uranium removal may reflect prior removal of uranium.

- There is evidence for interaction between Tank $50 \mathrm{H}$ solids with plutonium and neptunium as evidenced by loss of these two actinides from the salt solution.

- The amount of plutonium and neptunium lost from solution increased with an increase in the quantity of Tank $50 \mathrm{H}$ solids for a fixed simulant volume.

- The removal of plutonium and neptunium fit typical sorption isotherms allowing development of loading curves for estimating maximum solids loading.

- The maximum loading capacities for plutonium and neptunium in the simulants are, respectively, 2.01 and $4.48 \mu \mathrm{g}$ per gram of Tank $50 \mathrm{H}$ solids.

- The oxalate in the Tank $50 \mathrm{H}$ solids is not directly responsible for the loss of plutonium and neptunium from the salt solution. We attribute the removal of plutonium and neptunium to other minor components of the Tank $50 \mathrm{H}$ solids. We recommend additional testing to identify the component responsible for the plutonium and neptunium removal. 


\section{TABLE OF CONTENTS}

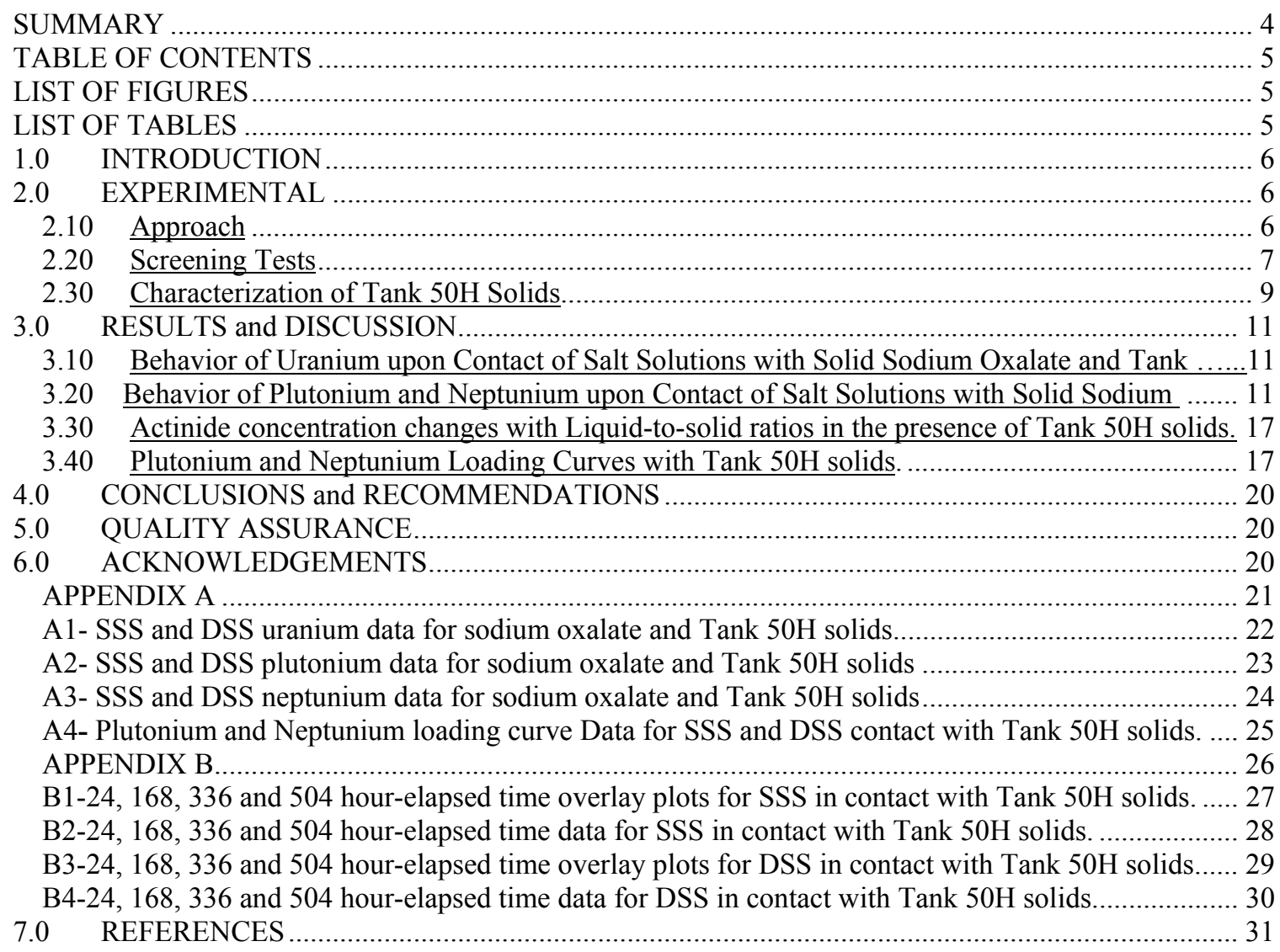

\section{LIST OF FIGURES}

Figure 1. Uranium: Tests with oxalate solids in SSS (A) and Tank 50H ....................... 12

Figure 2. Plutonium: Oxalate solids in SSS solution (D), Tank 50H solids in SSS ........ 13

Figure 3. Neptunium: Oxalate solids in SSS solutiont (G), Tank 50 H......................... 15

Figure 4. Actinide concentration in SSS and DSS solutions versus Liquid-to-............... 16

Figure 5. Plutonium and Neptunium Loading Curves.................................................... 19

\section{LIST OF TABLES}

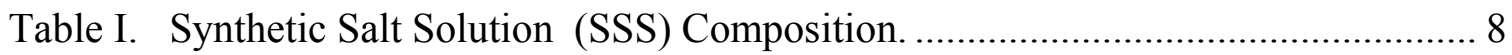

Table II. Decontaminated Salt (DSS) Composition.......................................................... 8

Table III. Major Cations, Anions and Actinides from Distilled Water-Leaches of the ... 10 


\subsection{INTRODUCTION}

Tank $50 \mathrm{H}$ is scheduled to return to HLW Tank Farm service and receive salt supernate solutions for feed to the Saltstone Facility. Camera inspections in Tank $50 \mathrm{H}$ recently revealed two large mounds ("North" and "south" mounds) of solid material, one in the vicinity of the B5 Riser Transfer Pump and the other on the opposite side of the tank ${ }^{\mathrm{i}}$. Estimates put the total volume of solids at approximately 61,000 gallons ${ }^{\text {ii }}$. These solids present a number of issues upon returning Tank $50 \mathrm{H}$ to HLW service. The sample analysis of Tank $50 \mathrm{H}$ solids indicated the presence of a significant fraction of sodium oxalate $(42.5 \mathrm{wt} \%)$ in the north mound solids ${ }^{\mathrm{iii}}$.

One option under consideration allows keeping the solids in Tank $50 \mathrm{H}$ and bringing lowcurie salt solution, as planned, into the tank before sending on to Saltstone. An issue with this option is what affect, if any, the oxalate-rich solids will have on the dissolved uranium and other actinides in the incoming salt solutions. The sodium oxalate in the solids may dissolve and bring about the precipitation and accumulation of any actinides such as uranium and plutonium. Since SRS wastes frequently contain enriched uranium and weapon-grade plutonium, accumulation of the uranium and plutonium in a solid phase is a possible criticality safety concern.

The original objective of this study was to determine if uranium precipitates upon contact of the Tank $50 \mathrm{H}$ mound solids with supernates containing uranium. However, during the initial test runs and characterizations for uranium, we found that other actinides (plutonium and neptunium), originally not considered as part of the test matrix, were not fully accounted for in the final mass balance in the simulant filtrates. Hence, we expanded the scope of the tests to include both plutonium and neptunium as well.

\subsection{EXPERIMENTAL}

\subsection{Approach}

The experimental plan called for the examination of the possibilities for actinide (uranium, and plutonium neptunium) precipitation or accumulation in the presence of Tank $50 \mathrm{H}$ solids in a 5.6 molar sodium salt solution (spiked with near saturation levels of uranium and plutonium) and a decontaminated waste solution prepared for earlier testing as a composite of supernate samples from Tank 44F and Tank $37 \mathrm{H}$. The composition of these two solutions is comparable to that expected to pass through the Tank $50 \mathrm{H}$ in the near future in support of the low-curie salt program and over the longer term from the Salt Waste Processing Facility.

We performed all tests at $25 \pm 1{ }^{\circ} \mathrm{C}$ in capped 150-ml polypropylene. In each test, we contacted an average of $5.012 \pm .015$ grams of the Tank $50 \mathrm{H}$ solids with varying amounts of either the 5.6 molar sodium salt solution (identified as SSS) or the decontaminated Tank 37K/44F composite waste solution (identified as DSS) ${ }^{\text {iv }}$ that had been spiked with additional uranium, plutonium and neptunium. The compositions of the solutions are summarized in Table 1 and 2. Prior to use in these tests, the DSS material had been used in three separate demonstrations: (1) strontium/actinide removal by monosodium titanate followed by caustic side solvent extraction for cesium removal, (2) large laboratory-scale 
test of strontium/actinide removal by monosodium titanate and (3) large laboratory-scale test of strontium/actinide removal by permanganate treatment.

One of the liquid-to-solid ratios used in these experiments is based on current estimates of solids in Tank $50 \mathrm{H}(61,000$ gallons $)$ and estimated quantity of supernate $(300,000$ gallons) derived from the dissolution of 100,000 gallons of saltcake from Tank $41 \mathrm{H}$. The calculated liquid-to-solids ratio $(300,000 / 61,000)$ for the test is $5: 1$. We also examined liquid-to-solid ratios of 3:1 and 10:1. Because of the limited quantity of Tank $50 \mathrm{H}$ solids, only the intermediate liquid-to-solid ratio of 5:1 was performed in duplicate. In addition to the tests with Tank $50 \mathrm{H}$ solids, two tests featured no added solids. These two tests served as controls and allow determination of possible cross contamination in samples.

Tank $50 \mathrm{H}$ solids $(5.012 \pm 0.015 \mathrm{~g})$ were put into each polypropylene bottle and the required volume of solution (SSS and DSS) was introduced to give the desired liquid-tosolid ratios. We performed a total of ten tests, five with SSS and five with DSS solutions.

The ten test bottles were put in an orbital shaker-water bath already equilibrated at $25 \pm 1$ ${ }^{\circ} \mathrm{C}$. We set the orbital shaker rate at $200 \mathrm{rpm}$. We sampled the test mixture after 24,168 , 336 and 504 hours of contact and filtered each sample through a 0.45 -micron nylon syringe filter disc to remove undissolved solids. We volumetrically acidified the filtrate with nitric acid and determined the actinide concentrations by inductively coupled plasma mass spectrometry (ICP-MS).

\subsection{Screening Tests}

Prior to acquiring of Tank $50 \mathrm{H}$ solids for these actinide tests, preliminary screening test were performed with sodium oxalate, which is a major constituent (42.5 wt \%) of the Tank $50 \mathrm{H}$ solids isolated from the north mound of Tank $50 \mathrm{H}$. In the screening test, we contacted the SSS simulant with reagent grade sodium oxalate at a volume ratio of 12:1. We derived this ratio by taking the 5:1 ratio from above and correcting for sodium oxalate content in the solids (42.5 WT \%) and assuming that the sodium oxalate and other Tank $50 \mathrm{H}$ solids have the same solid densities. Agitation in this test was provided by a magnetic stirrer and a Teflon coated magnetic stirring bar inserted into the test mixture. 
Table I. Synthetic Salt Solution (SSS) Composition.

\begin{tabular}{|l|c|c|}
\hline \multicolumn{1}{|c|}{ Component } & Target concentration & Units \\
\hline Total $\mathrm{Na}$ & 5.60 & $\mathrm{M}$ \\
\hline Free $\mathrm{NaOH}$ & $1.33 \mathrm{E}+00$ & $\mathrm{M}$ \\
\hline $\mathrm{NaNO}_{3}$ & $2.60 \mathrm{E}+00$ & $\mathrm{M}$ \\
\hline $\mathrm{NaNO}_{2}$ & $1.64 \mathrm{E}-01$ & $\mathrm{M}$ \\
\hline $\mathrm{Na}_{2} \mathrm{SO}_{4}$ & $5.21 \mathrm{E}-01$ & $\mathrm{M}$ \\
\hline $\mathrm{Na}_{2} \mathrm{CO}_{3}$ & $2.60 \mathrm{E}-02$ & $\mathrm{M}$ \\
\hline $\mathrm{NaAl}(\mathrm{OH})_{4}$ & $4.29 \mathrm{E}-01$ & \\
\hline & & $\mathrm{mg} / \mathrm{L}$ \\
\hline Total U & $13.65 \pm 1$ & $\mu \mathrm{g} / \mathrm{L}$ \\
\hline Total $\mathrm{Pu}$ & $275 \pm 20$ & $\mu \mathrm{g} / \mathrm{L}$ \\
\hline $\mathrm{Np}-237$ & $650 \pm 60$ & \\
\hline
\end{tabular}

Table II. Decontaminated Salt Solution (DSS) Composition (ref. iv)

\begin{tabular}{|l|c|c|}
\hline \multicolumn{1}{|c|}{ Component } & Concentration & Units \\
\hline $\mathrm{Na}$ & 9.16 & $\mathrm{M}$ \\
\hline $\mathrm{K}$ & 0.06 & $\mathrm{M}$ \\
\hline $\mathrm{Ag}$ & 9.46 & $\mathrm{mg} / \mathrm{L}$ \\
\hline $\mathrm{Ba}$ & 2.82 & $\mathrm{mg} / \mathrm{L}$ \\
\hline $\mathrm{Ca}$ & 19.92 & $\mathrm{mg} / \mathrm{L}$ \\
\hline $\mathrm{Cd}$ & 2.16 & $\mathrm{mg} / \mathrm{L}$ \\
\hline $\mathrm{Cr}$ & 64 & $\mathrm{mg} / \mathrm{L}$ \\
\hline $\mathrm{Mo}$ & 78 & $\mathrm{mg} / \mathrm{L}$ \\
\hline $\mathrm{Free} \mathrm{OH}^{-}$ & 6.81 & $\mathrm{M}$ \\
\hline $\mathrm{NO}_{3-}{ }^{-}$ & 0.95 & $\mathrm{M}$ \\
\hline $\mathrm{NO}_{2}{ }^{-}$ & 0.68 & $\mathrm{M}$ \\
\hline $\mathrm{AlO}_{2}{ }^{-}$ & 0.30 & $\mathrm{M}$ \\
\hline $\mathrm{SO}_{4}{ }^{2-}$ & 0.07 & $\mathrm{M}$ \\
\hline $\mathrm{CO}_{3}{ }^{2-}$ & 0.11 & $\mathrm{M}$ \\
\hline $\mathrm{PO}_{4}{ }^{3-}$ & 0.01 & $\mathrm{M}$ \\
\hline & & $\mathrm{mg} / \mathrm{L}$ \\
\hline $\mathrm{Total} \mathrm{Uranium}$ & $19 \pm 1$ & $\mu \mathrm{g} / \mathrm{L}$ \\
\hline $\mathrm{Total} \mathrm{Pu}$ & $52 \pm 5$ & \\
\hline
\end{tabular}




\subsection{Characterization of Tank $50 \mathrm{H}$ Solids}

The moisture content of Tank $50 \mathrm{H}$ solids was determined by exposing known amounts in a negative pressure hood with constant airflow and a desiccator for several weeks. The samples were weighed every other day until constant weight. The average moisture content obtained for tank $50 \mathrm{H}$ solids measured $13.4 \pm 0.6$ weight percent.

Oxalate anion concentration in Tank $50 \mathrm{H}$ solids was determined by two methods: direct acid digestion of the solid and analysis of the filtrate by ion chromatography (IC) and distilled water leaching of the solids over night and analysis of the filtrate by IC.

Oxalate concentration measured $0.3565 \pm 0.0344$ gram oxalate per gram of Tank $50 \mathrm{H}$ solids from the acid digestions and $0.3431 \pm 0.047$ gram oxalate per gram of Tank $50 \mathrm{H}$ solids from the distilled water leachates. These results indicate that more than $95 \%$ of the oxalate in the composite Tank $50 \mathrm{H}$ solids dissolved in water.

We also analyzed the filtered water leachates for actinide content by ICP-MS.

The uranium concentration measured $0.365 \pm 0.03 \mathrm{mg}$ uranium per gram of Tank $50 \mathrm{H}$ solids. This corresponds to an addition of $1.65 \pm 0.35 \mathrm{mg}$ uranium in each test. No plutonium was measured in the Tank $50 \mathrm{H}$ solids and only $1.18 \mathrm{E}-03 \pm 1.15 \mathrm{E}-04 \mathrm{mg}$ neptunium per gram of Tank $50 \mathrm{H}$ solids was measured (see Table III below). 
Table III. Major Cations, Anions and Actinides from Distilled Water-Leaches of the Tank 50H Solids.

\begin{tabular}{|c|c|c|c|c|c|}
\hline Cations & $\begin{array}{c}\text { First } \\
\text { Leachate }\end{array}$ & $\begin{array}{c}\text { Second } \\
\text { Leachate }\end{array}$ & Average & Units & $\begin{array}{c}\text { mg/g Tank } 50 H \\
\text { solids }\end{array}$ \\
\hline $\mathrm{Al}$ & 38.9 & 39 & 38.95 & $\mathrm{mg} / \mathrm{L}$ & 0.784 \\
\hline $\mathrm{B}$ & 3.15 & 3.07 & 3.11 & $\mathrm{mg} / \mathrm{L}$ & 0.063 \\
\hline $\mathrm{Ca}$ & 0.936 & 1.1 & 1.018 & $\mathrm{mg} / \mathrm{L}$ & 0.020 \\
\hline $\mathrm{Ce}$ & 0.397 & 0.481 & 0.439 & $\mathrm{mg} / \mathrm{L}$ & 0.009 \\
\hline $\mathrm{Cr}$ & 0.559 & 0.556 & 0.558 & $\mathrm{mg} / \mathrm{L}$ & 0.011 \\
\hline $\mathrm{Cu}$ & 0.451 & 0.446 & 0.449 & $\mathrm{mg} / \mathrm{L}$ & 0.009 \\
\hline $\mathrm{Fe}$ & 0.333 & 0.321 & 0.327 & $\mathrm{mg} / \mathrm{L}$ & 0.007 \\
\hline $\mathrm{Mg}$ & 0.196 & 0.193 & 0.195 & $\mathrm{mg} / \mathrm{L}$ & 0.004 \\
\hline $\mathrm{Na}$ & 14100 & 14000 & 14050 & $\mathrm{mg} / \mathrm{L}$ & 282.7 \\
\hline $\mathrm{P}$ & 7.6 & 7.66 & 7.63 & $\mathrm{mg} / \mathrm{L}$ & 0.154 \\
\hline $\mathrm{Si}$ & 0.3632 & 0.609 & 0.620 & $\mathrm{mg} / \mathrm{L}$ & 0.012 \\
\hline $\mathrm{Sn}$ & 0.658 & 0.727 & 0.693 & $\mathrm{mg} / \mathrm{L}$ & 0.014 \\
\hline $\mathrm{Sr}$ & 0.221 & 0.267 & 0.244 & $\mathrm{mg} / \mathrm{L}$ & 0.005 \\
\hline Total U & 0.344 & 0.387 & $0.365 \pm 0.030$ & $\begin{array}{c}\mathrm{mg} \mathrm{U} / \mathrm{g} \text { Tank } \\
50 \mathrm{H} \text { solids }\end{array}$ & $0.365 \pm 0.030$ \\
\hline $\mathrm{Np}-237$ & $1.07 \mathrm{E}-03$ & $1.28 \mathrm{E}-03$ & $\begin{array}{c}1.18 \mathrm{E}-03 \\
\pm 1.5 \mathrm{E}-04 \\
\end{array}$ & $\begin{array}{c}\text { mg Np/g Tank } \\
50 \mathrm{H} \text { solids }\end{array}$ & $\begin{array}{c}1.18 \mathrm{E}-03 \\
\pm 1.5 \mathrm{E}-04 \\
\end{array}$ \\
\hline $\begin{array}{l}\text { Oxalate } \\
\text { anion }\end{array}$ & 343 & 356 & $350 \pm 9$ & $\begin{array}{c}\mathrm{mg} / \mathrm{g} \text { Tank } \\
50 \mathrm{H} \text { solids }\end{array}$ & $350 \pm 9$ \\
\hline
\end{tabular}




\subsection{RESULTS and DISCUSSION}

3.10 Behavior of Uranium upon Contact of Salt Solutions with Solid Sodium Oxalate and Tank $50 \mathrm{H}$ Solids

Figure 1(inserts A, B and C) shows overlay uranium concentration-time profiles for tests in which we contacted the SSS and DSS solutions with sodium oxalate solids and Tank $50 \mathrm{H}$ solids. Insert A is the uranium profile for the test with SSS and solid sodium oxalate. The average uranium concentration for the control test without sodium oxalate solids, labeled as untreated, measured $13.5 \pm 2.1 \mathrm{mg} / \mathrm{L}$. For the tests with sodium oxalate solids (labeled treated), the uranium concentration averaged $12.2 \pm 0.67 \mathrm{mg} / \mathrm{L}$. (see appendix A, tables A1 for a complete listing of the measured uranium concentrations).

Insert B in Figure 1 shows the uranium concentration-time profile plots for the SSS solution with (treated) and without (untreated) Tank $50 \mathrm{H}$ solids. The uranium concentration for the test with Tank $50 \mathrm{H}$ solids averaged $14.43 \pm 0.51 \mathrm{mg} / \mathrm{L}$, versus that without solids at $14.62 \pm 0.58 \mathrm{mg} / \mathrm{L}$. It is worth noting that Tank $50 \mathrm{H}$ solids $(5.012 \pm$ $0.015 \mathrm{~g}$ ) used in each test may contribute as much as $1.65 \mathrm{mg}$ uranium to the over all uranium concentration (see characterization of Tank $50 \mathrm{H}$ solids). Thus we conclude that Tank $50 \mathrm{H}$ solids do not precipitate uranium from the SSS solution.

Insert $\mathrm{C}$ in Figure 1 shows a similar uranium concentration-time profile plot for contact of the DSS solution with Tank $50 \mathrm{H}$ solids (see Appendix A, Table A1 for experimental data). In this test the uranium concentration for the untreated sample averaged $18.14 \pm$ $0.63 \mathrm{mg} / \mathrm{L}$ compared to the treated sample of $18.40 \pm 0.34 \mathrm{mg} / \mathrm{L}$. Again, there is statistically no difference in the uranium concentrations between the untreated and treated tests with Tank $50 \mathrm{H}$ solids; indicating no precipitation of uranium.

Based on these findings with the SSS and DSS solutions in contact with sodium oxalate and Tank $50 \mathrm{H}$ solids, we conclude that neither material interacts with the uranium in solution to produce a uranium precipitate. This lack of interaction between Tank $50 \mathrm{H}$ solids and the SSS and DSS solutions may be due to relatively high uranium concentration in the solids $(0.36 \mathrm{mg} / \mathrm{g})$, which serves to limit the sorption of uranium from solution onto the solids.

3.20 Behavior of Plutonium and Neptunium upon Contact of Salt Solutions with Solid Sodium Oxalate and Tank 50H solids.

Figure 2 (inserts D, E and F) shows overlay plutonium concentration-time profiles tests in which we contacted the SSS and DSS solutions with sodium oxalate solids and simulant tests with Tank $50 \mathrm{H}$ solids. Insert $\mathrm{D}$ is the plutonium profile for tests with the SSS solution and sodium oxalate solids. The average plutonium concentration for the control test without sodium oxalate solids (labeled untreated) measured $276 \pm 59 \mu \mathrm{g} / \mathrm{L}$. For the tests with sodium oxalate solids (labeled treated) the average plutonium measured was $264 \pm 31.1 \mu \mathrm{g} / \mathrm{L}$ (see Appendix A, Table A2 for complete listing of plutonium data). The 
average concentrations are not statistically different. Thus we conclude that contact of the SSS solution with sodium oxalate does not precipitate uranium.

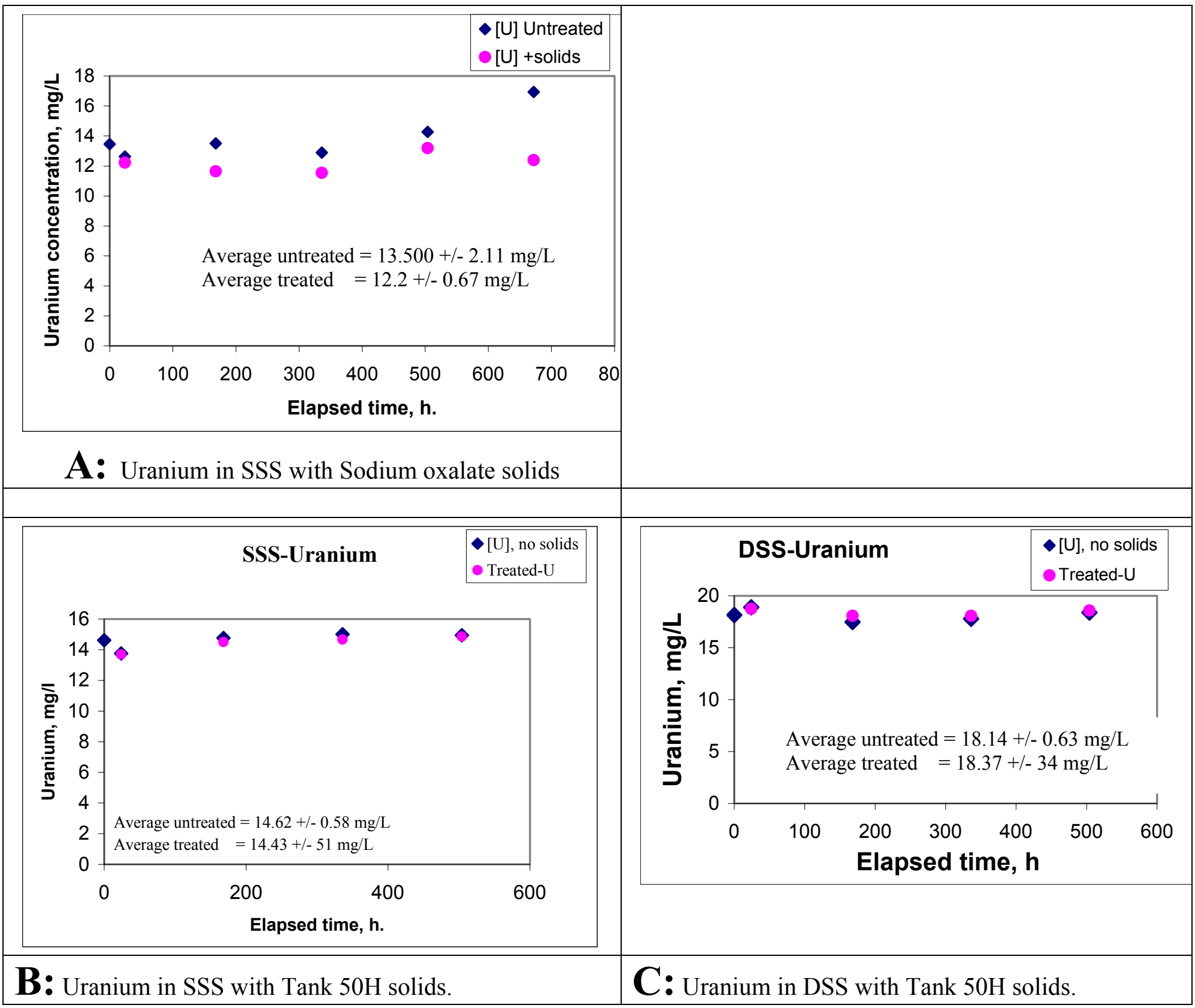

Figure 1. Uranium: Tests with oxalate solids in SSS (A) and Tank 50H solids in SSS and DSS solutions (B and C). 


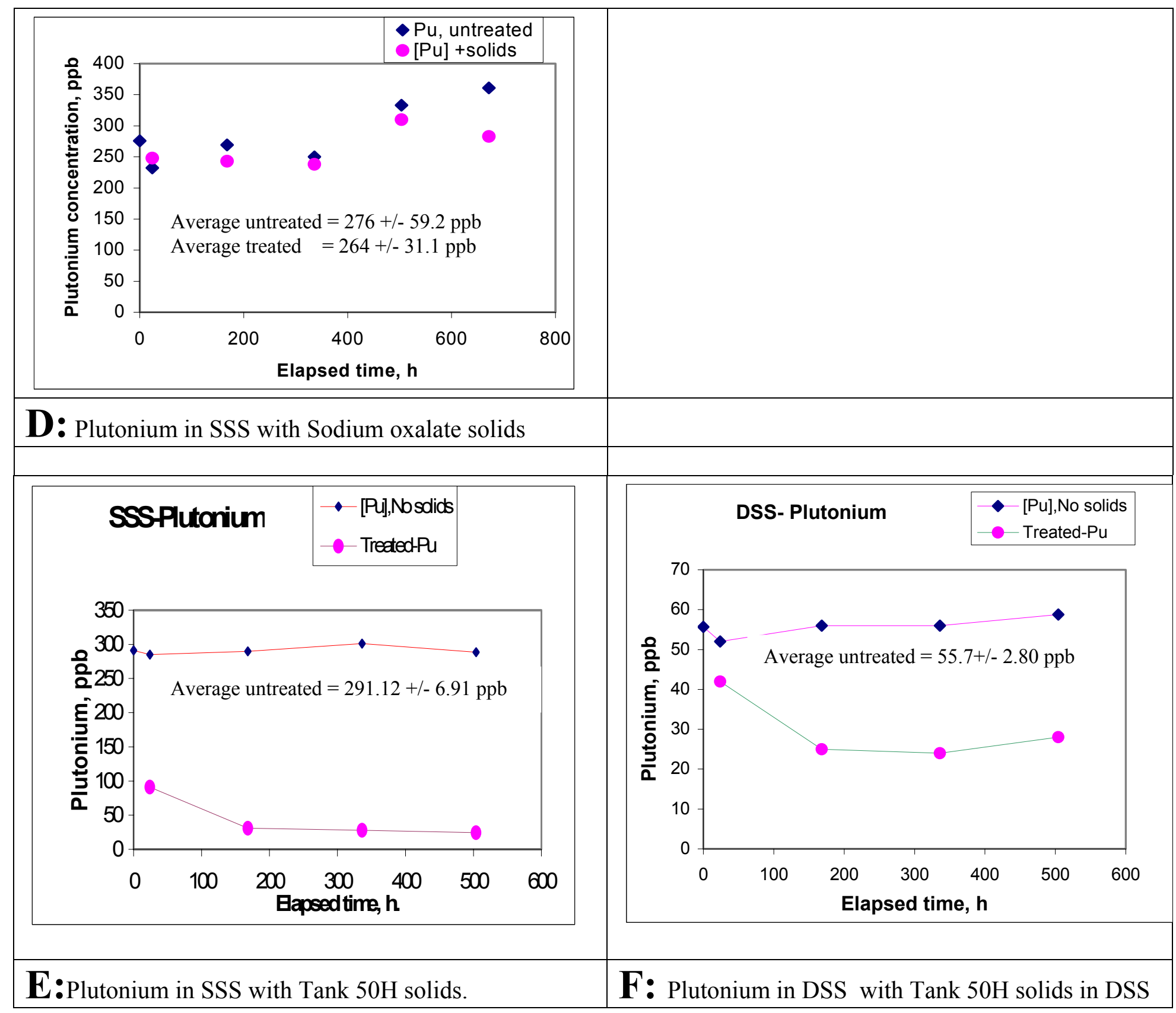

Figure 2. Plutonium: Oxalate solids in SSS solution (D), Tank 50H solids in SSS and DSS solutions ( $\mathrm{E}$ and $\mathrm{F}$ ). 
Insert $\mathrm{E}$ in Figure 2 shows the overlay plutonium concentration-time profile plots for the contact of SSS solution with Tank 50H solids (treated) and the SSS solution without solids (untreated). Within the first 24 hours of exposing the SSS solution to Tank $50 \mathrm{H}$ solids, we observed the removal of over $65 \%$ of the plutonium (see Appendix A, Table A2 for experimental data). Plutonium removal increased to more than $90 \%$ after 168 hours of contact.

We also observed plutonium removal upon contact of the DSS solution with Tank $50 \mathrm{H}$ solids. The total masses and percent removed were lower in the test with the DSS solution. For example, plutonium removal measured $24 \%$ after 24 hours of contact and $55 \%$ after 168 hours. This is not unexpected given the lower initial plutonium concentration in the DSS solution $(55.7 \pm 2.8 \mu \mathrm{g} / \mathrm{L})$ compared to that in the SSS solution $(276 \pm 59 \mu \mathrm{g} / \mathrm{L})$.

Insert $\mathrm{G}$ in Figure 3 shows the overlay neptunium concentration-time profiles for the test with the SSS solution and sodium oxalate solids. The average untreated neptunium concentration for the untreated solution measured $572 \pm 56 \mu \mathrm{g} / \mathrm{L}$ compared to that of the treated solution at $536 \pm \mu \mathrm{g} / \mathrm{L}$. Again, there is no statistical difference in neptunium concentrations between the untreated SSS solution and that contacted with sodium oxalic solids. Hence we conclude that there is no loss of neptunium in the presence of sodium oxalate solids.

Insert $\mathrm{H}$ in Figure 3 shows the overlay neptunium concentration-time profiles plot for the SSS solution with and without the addition of the Tank $50 \mathrm{H}$ solids. Within the first 24 hours of contact with the Tank $50 \mathrm{H}$ solids, we observed the loss of over $60 \%$ of the neptunium (see Appendix A, Table A3 for experimental data). After 168 hours of contact, we measured more than $77 \%$ removal of the neptunium. Thus, we conclude that the tank $50 \mathrm{H}$ solids react with both plutonium and neptunium in the SSS solution. The reaction must not occur with the sodium oxalate that is present in the Tank $50 \mathrm{H}$ solids since no reaction is observed between the SSS solution and reagent grade sodium oxalate.

The mechanism responsible for the plutonium and neptunium removal has not been identified, but it is conjectured to be actinide reduction of some sort followed by precipitation and/or sorption. Additional testing would be required to identify the specific removal mechanism and determine how to mitigate. 


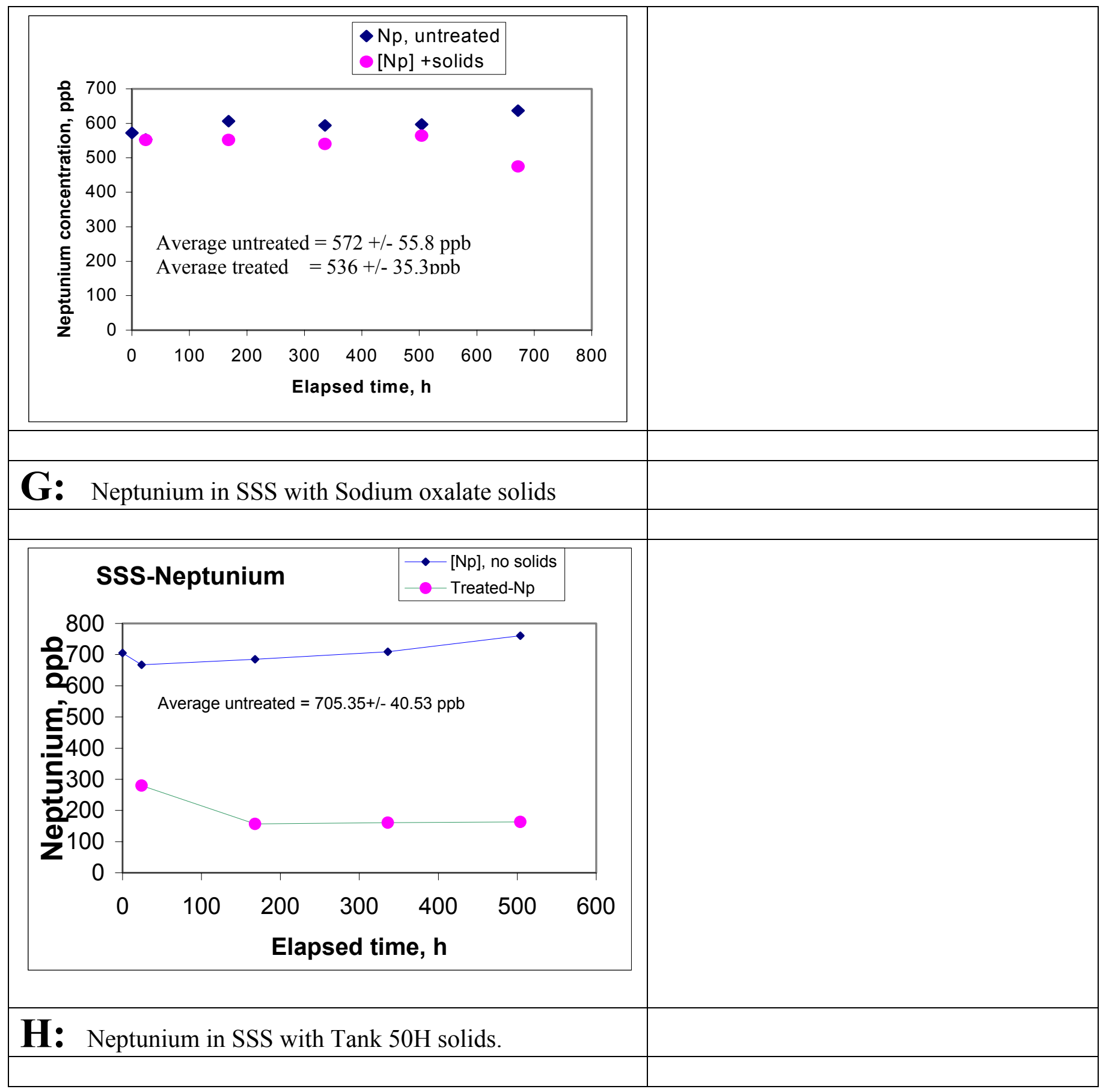

Figure 3. Neptunium: Oxalate solids in SSS solutiont (G), Tank $50 \mathrm{H}$ solids in SSS (H). 


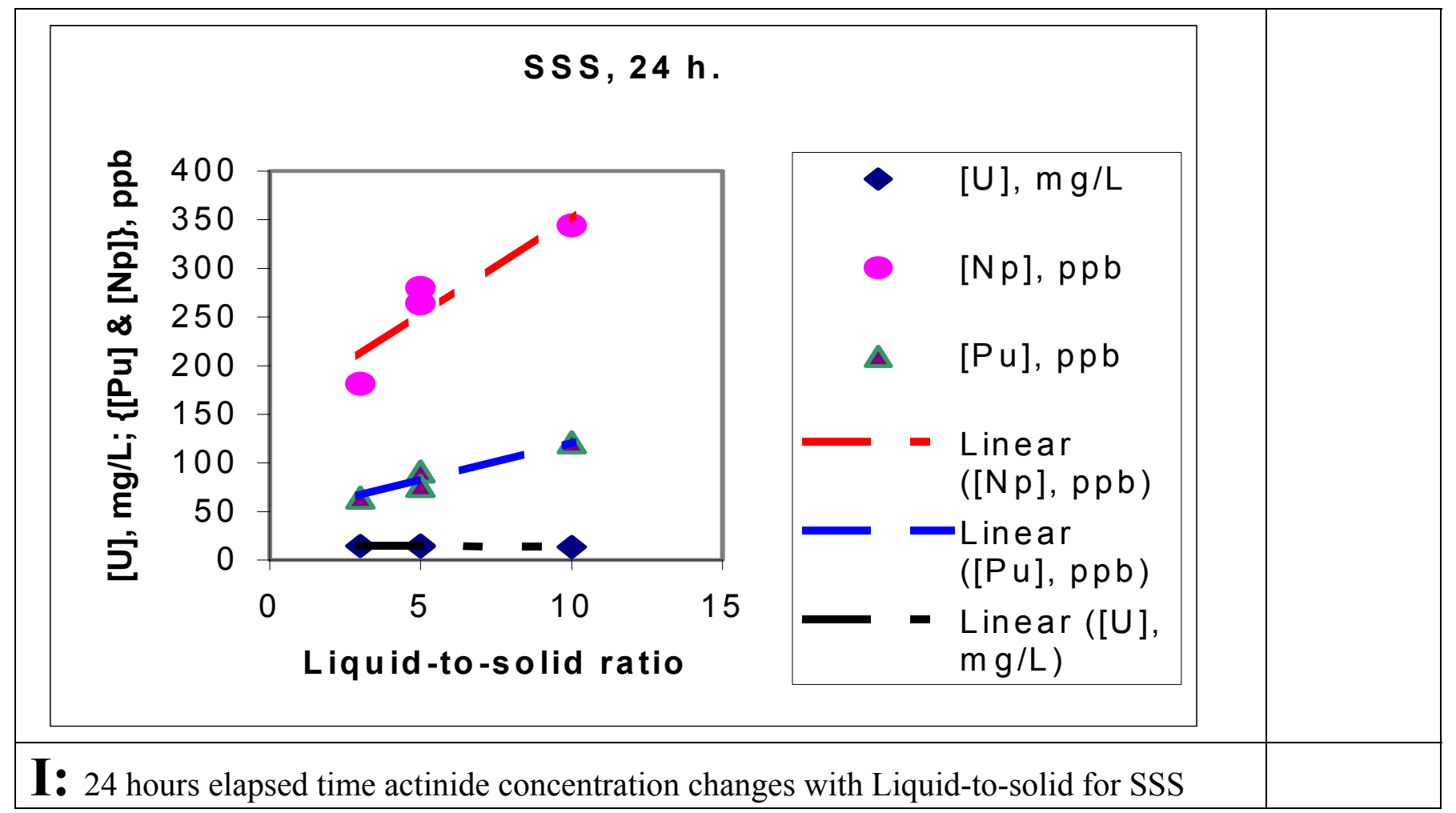

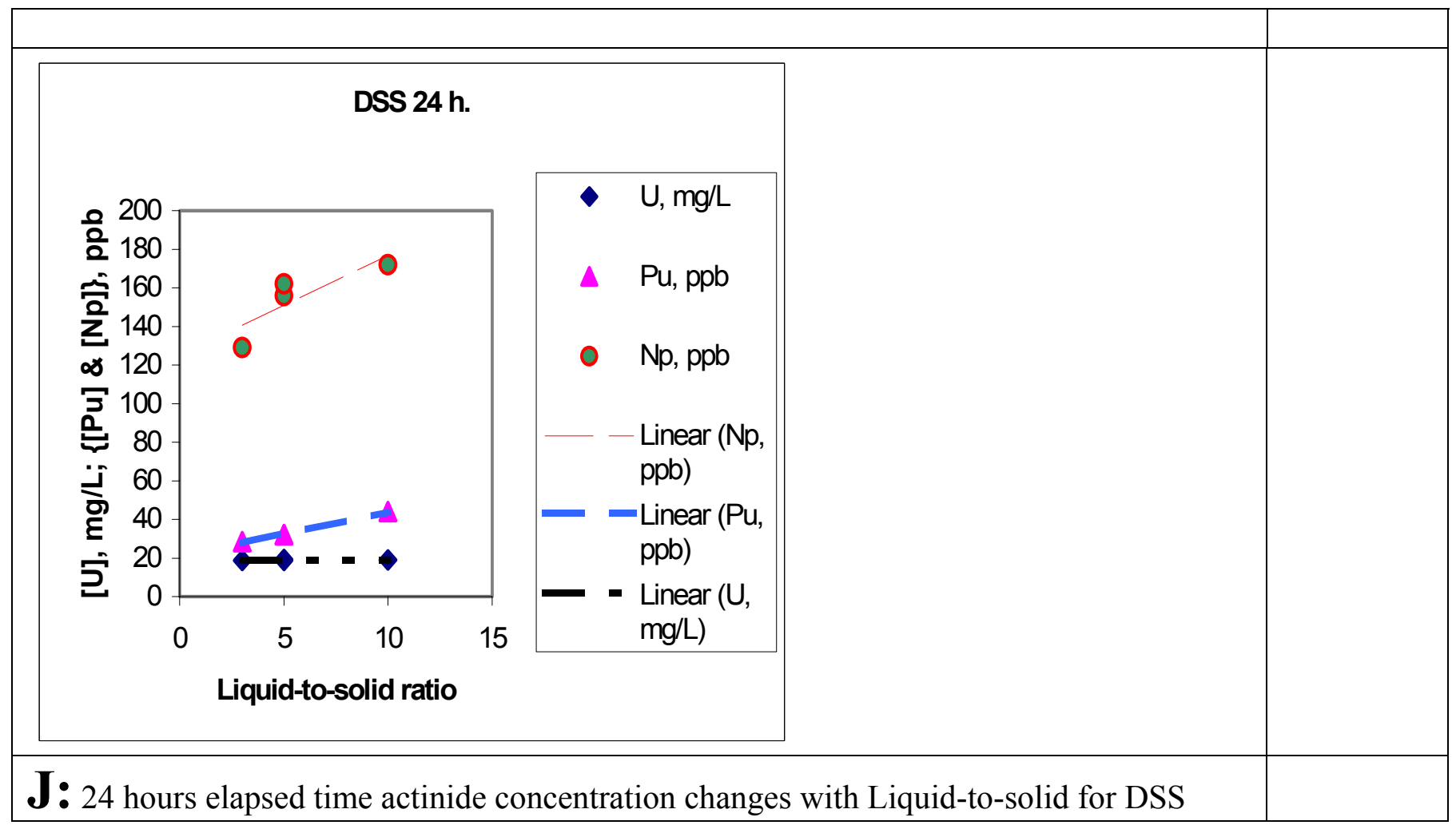

Figure 4. Actinide concentration in SSS and DSS solutions versus Liquid-tosolid ratios. 
3.30 Actinide concentration changes with Liquid-to-solid ratios in the presence of Tank $50 \mathrm{H}$ solids.

Figure 4 shows overlay plots the 24 hour-elapsed time actinide concentration changes as a function of the liquid-to-solid ratios for the tests with SSS and DSS solutions in contact with Tank $50 \mathrm{H}$ solids. In both overlay plots, as the liquid-to-solid ratios decrease (increase in Tank $50 \mathrm{H}$ solid fraction) the amount of plutonium and neptunium precipitated or lost from the liquid phase increased. This behavior is consistent with typical sorption suggesting that plutonium and neptunium are sorbing onto one or more of the components in the Tank $50 \mathrm{H}$ solids. We observed this same behavior at the other sampling times (168, 336 and 504 hours). Appendix B provides the experimental data and plots for the 168, 336 and 504 hours samples. Note that we observed no loss in uranium in any of the tests with varying liquid-to-solid ratios.

3.40 Plutonium and Neptunium Loading Curves with Tank 50H solids.

Figure 5, inserts $\mathrm{K}$ and $\mathrm{L}$, provide plutonium and neptunium loading curves, respectively, for the Tank $50 \mathrm{H}$ solids after 504 hours of exposing Tank $50 \mathrm{H}$ solids of contact with the SSS and DSS solutions. Appendix A, Table A4 provides the experimental data. Data for the lower portions of the loading curves are data from the tests with the DSS solutions, whereas the higher loadings are from tests with the SSS solutions. The higher loadings with the SSS solutions result from the higher initial concentrations of plutonium and neptunium in this solution compared to the DSS solution.

The loading curve information is useful in estimating the volume of Tank Farm supernates that can be transferred into the Tank before accumulating significant quantities of plutonium that represent a nuclear criticality safety concern. Conversely, the information could also be used to determine how much of the Tank solids could be left behind and not represent a safety concern due to the accumulation of plutonium. Regression of the data provides the following equations for estimating maximum loading of plutonium and neptunium.

$y=-0.3335 x^{2}+65.497 x-1205.9$ for plutonium and

$\mathrm{y}=-0.029 \mathrm{x}^{2}+23.126 \mathrm{x}$ for neptunium,

where $\mathrm{y}$ is loading capacity in units of $\mu \mathrm{g}$ actinide per gram of Tank $50 \mathrm{H}$ solids and $\mathrm{x}$ is the final actinide concentration in $\mu \mathrm{g} / \mathrm{L}$.

By equating the first derivatives of the above two loading capacity equations to zero and solving for $\mathrm{x}$ values, the maximum loading capacities (y-values) for plutonium and Neptunium are, respectively, 2.01 and $4.48 \mu \mathrm{g}$ per gram of Tank $50 \mathrm{H}$ solids. 


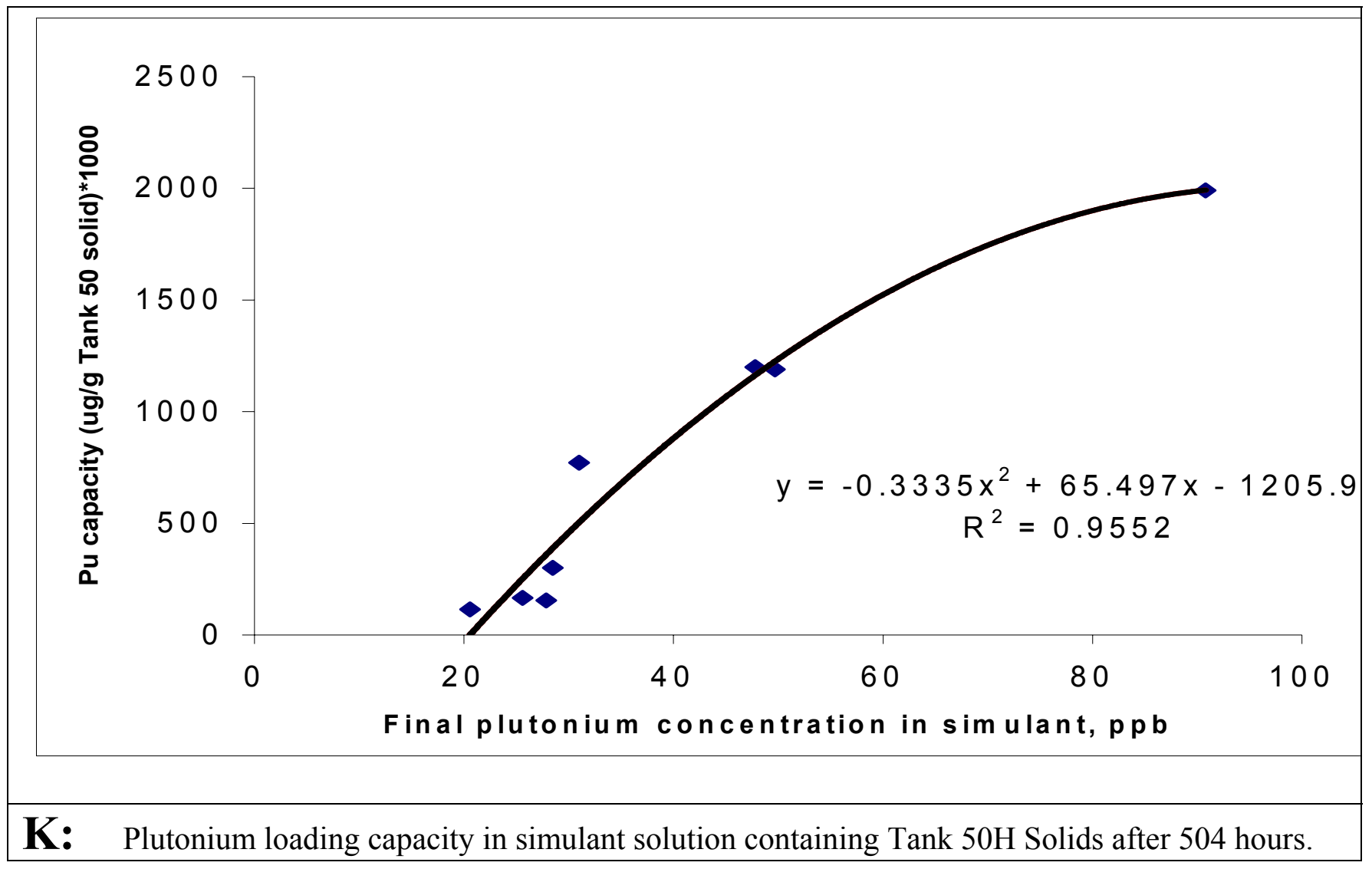




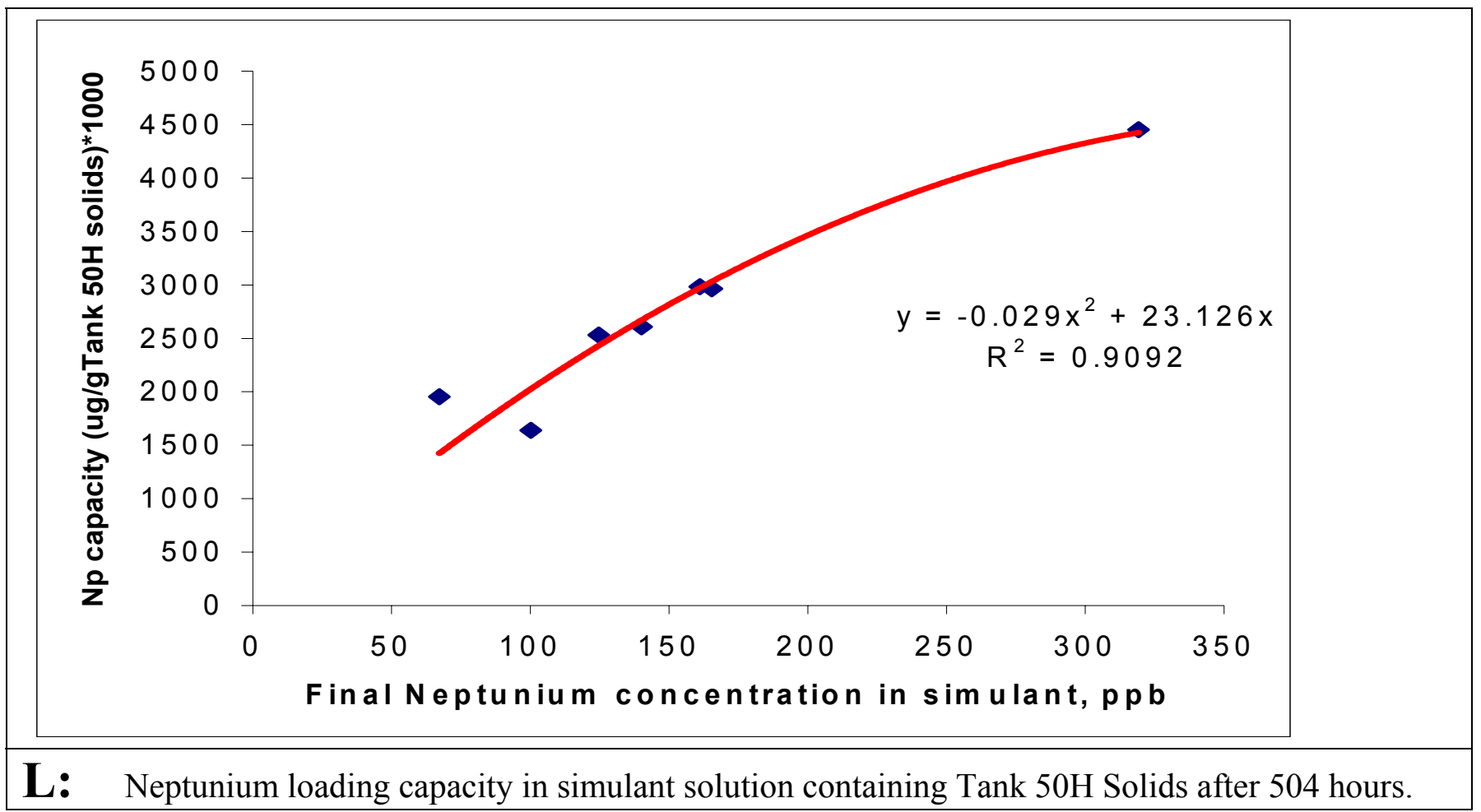

Figure 5. Plutonium and Neptunium Loading Curves. 


\subsection{CONCLUSIONS and RECOMMENDATIONS}

We conducted a series of tests to evaluate the interaction of sodium oxalate and Tank $50 \mathrm{H}$ solids with actinide dissolved in simulated and tank waste solutions. From these tests we conclude the following:

- Greater than $90 \%$ of the oxalate in the Tank $50 \mathrm{H}$ solids is water soluble,

- There is no interaction between sodium oxalate solids and uranium, plutonium and neptunium dissolved in simulated and tank waste solutions,

- There is no interaction between Tank $50 \mathrm{H}$ solids and uranium dissolved in simulated and tank waste solutions,

- There is no evidence of uranium removal upon contact of Tank $50 \mathrm{H}$ solids with simulated and tank waste solutions,

-Lack of uranium removal may reflect prior removal of uranium.

- Tank $50 \mathrm{H}$ solids effectively removed plutonium and neptunium from simulated and tank waste solutions. The mechanism responsible for the plutonium and neptunium removal has not been identified, but it is conjectured to be reduction of some sort followed by precipitation and/or sorption.

- The removal of plutonium and neptunium fit typical sorption isotherms allowing development of loading curves for estimating maximum solids loading.

- The maximum loading capacities for plutonium and neptunium are, respectively, 2.01 and $4.48 \mu \mathrm{g}$ per gram of Tank $50 \mathrm{H}$ solids.

- We recommend that additional tests be conducted to identify the component (s) responsible for the removal of plutonium and neptunium and possibly uranium from the alkaline waste solutions.

\subsection{QUALITY ASSURANCE}

This study fulfills the activity defined in Task Technical and Quality Assurance Plan:

"Evaluation of the Effects of Tank 50H solid on Dissolved Uranium" WSRC-RP-200101096, Rev.0, Dec. 13,2001. Data obtained from this study reside as records in WSRCLB-2001-00179.

\subsection{ACKNOWLEDGEMENTS}

The authors thank Analytical Development Section personnel, in particular, B. Boyce, M. Malek, R. Ray and J. Hart for performing actinide anion and other metal analyses. We also thank M. S. Blume for assistance in running the experiments. 


\section{APPENDIX A}

Data for uranium in simulants: SSS containing sodium oxalate, SSS and DSS containing Tank $50 \mathrm{H}$ solids. 
A1- SSS and DSS uranium data for sodium oxalate and Tank 50H solids

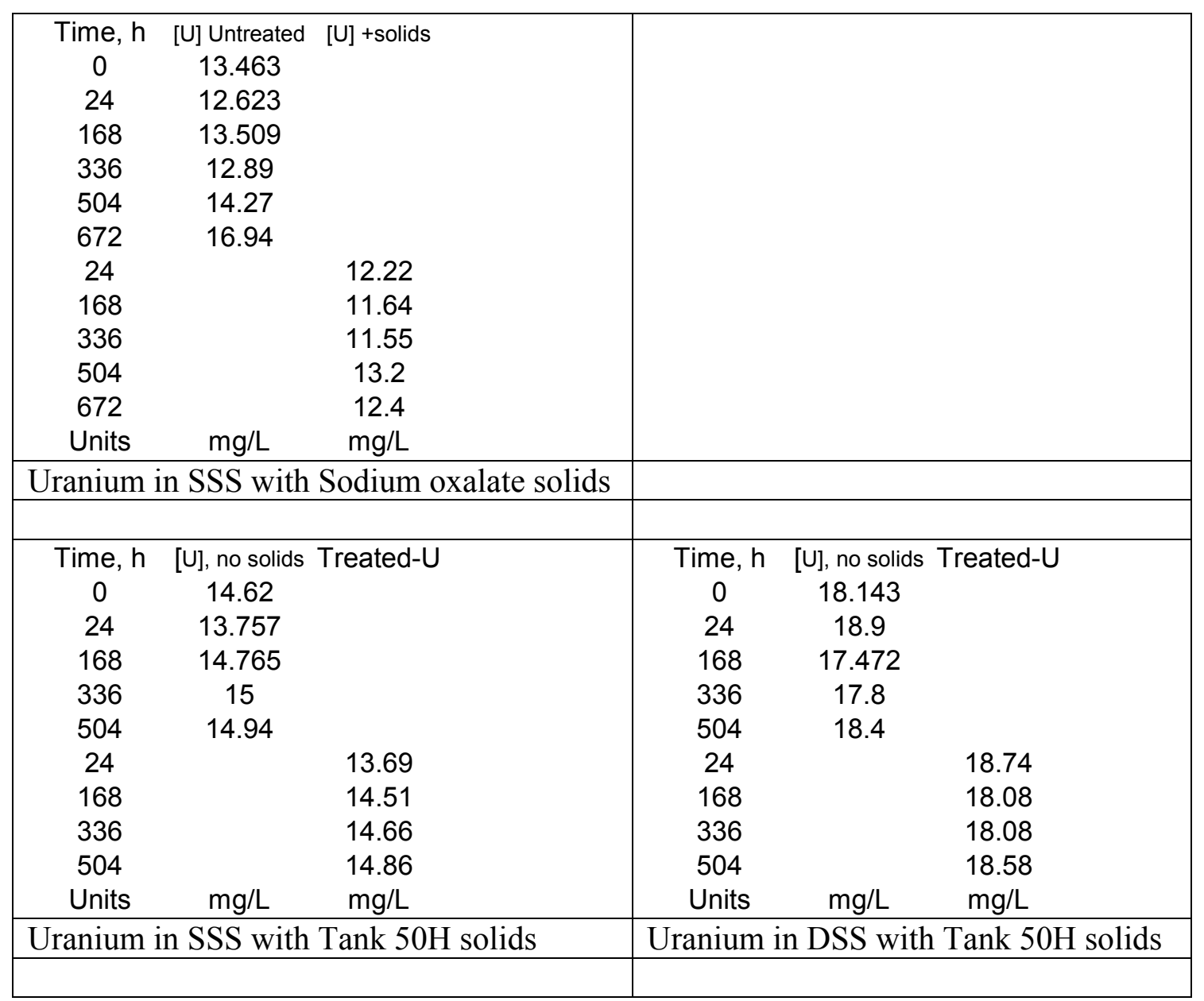


A2- SSS and DSS plutonium data for sodium oxalate and Tank 50H solids

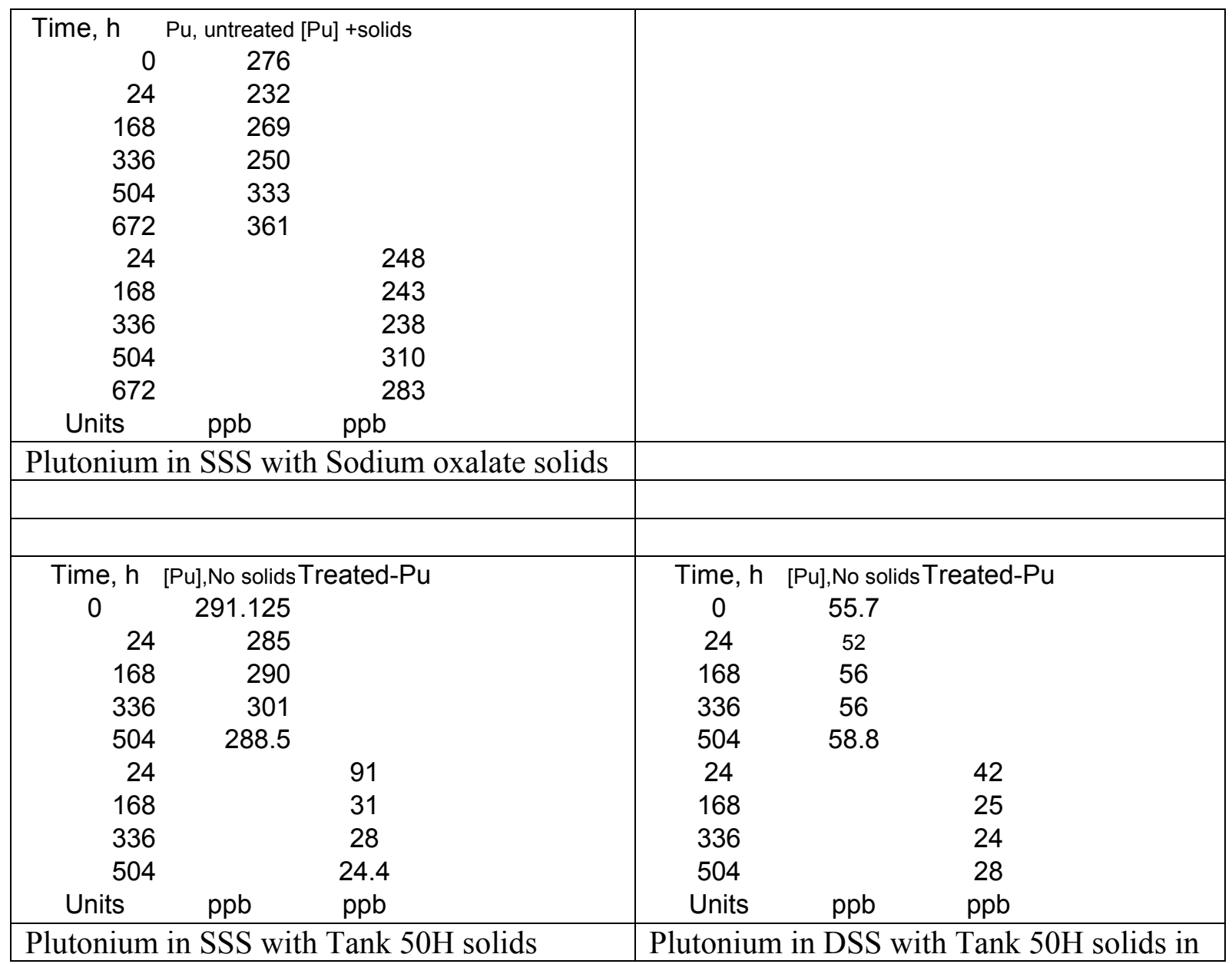


A3- SSS and DSS neptunium data for sodium oxalate and Tank 50H solids

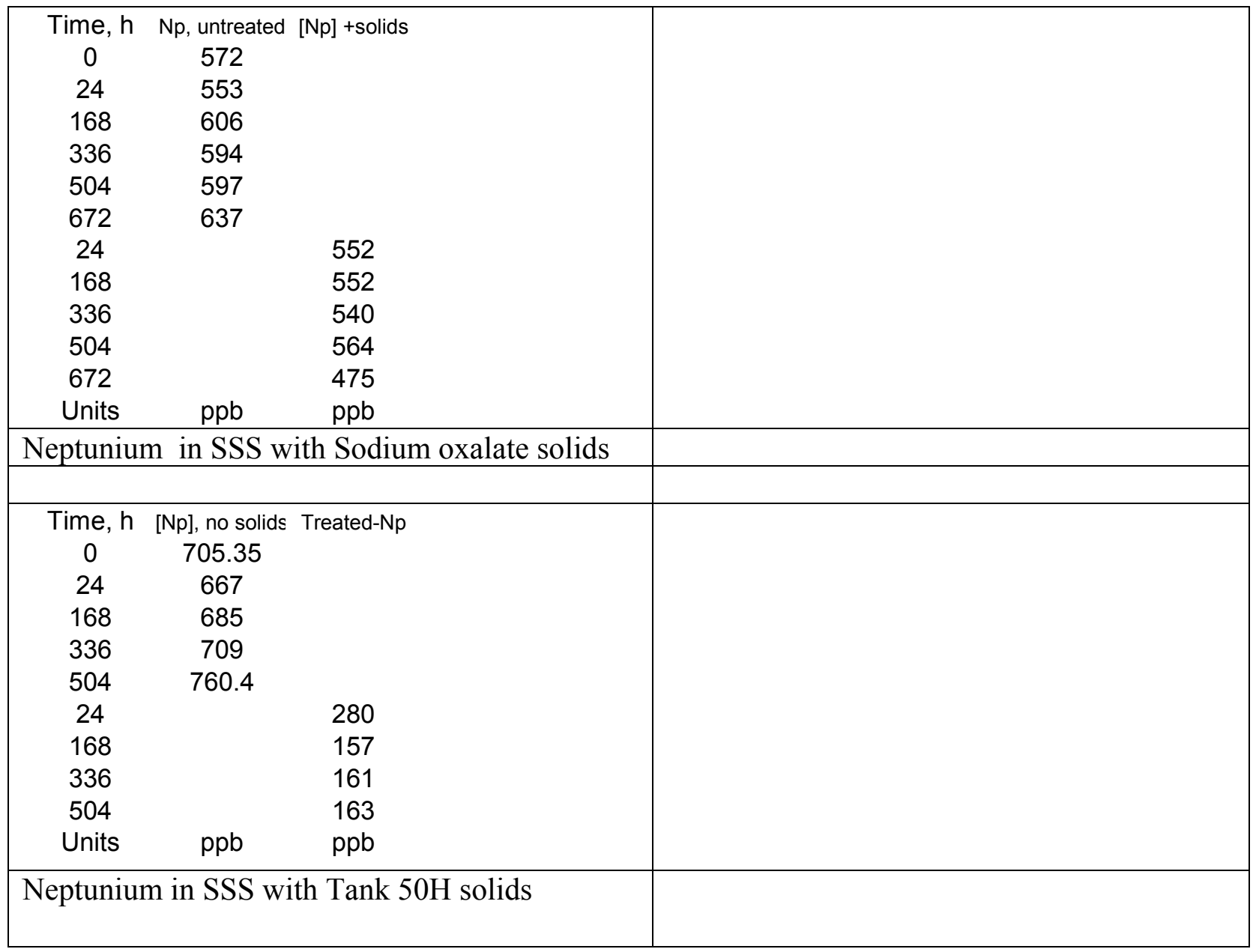


A4- Plutonium and Neptunium loading curve Data for SSS and DSS contact with Tank $50 \mathrm{H}$ solids.

\begin{tabular}{|c|c|c|c|c|c|}
\hline $\begin{array}{r}\text { Pu-Fin. Ppb } \\
90.8\end{array}$ & $\begin{array}{l}\text { ugPu/gTank } 50 \mathrm{H} \text { solid*1000 } \\
1990.737\end{array}$ & atio & $\begin{array}{r}\text { Np-Fin. Ppb } \\
319.2\end{array}$ & $\begin{array}{l}\text { ug Np/g Tank 50H solid } \\
4450.362\end{array}$ & $* 1000$ \\
\hline 47.8 & 1199.04 & & 165.32 & 2964.19 & \\
\hline 49.68 & 1189.205 & & 161.12 & 2983.918 & \\
\hline 30.99 & 771.5099 & & 67.23 & 1953.146 & \\
\hline 28.48 & 300.6743 & & & & \\
\hline 25.6 & 165.8 & & 140 & 2606.72 & \\
\hline 27.86 & 154.52 & & 124.6 & 2529.81 & \\
\hline 20.58 & 114.68 & & 100.11 & 1639.71 & \\
\hline \multicolumn{2}{|c|}{ Plutonium loading curve data } & \multicolumn{4}{|c|}{ Neptunium loading curve data } \\
\hline
\end{tabular}




\section{APPENDIX B}

Overlay plots and experimental data for actinide concentration changes with liquid-tosolid ratios for SSS and DSS contact with Tank $50 \mathrm{H}$ solids. 
B1-24, 168, 336 and 504 hour-elapsed time overlay plots for SSS in contact with Tank 50H solids.

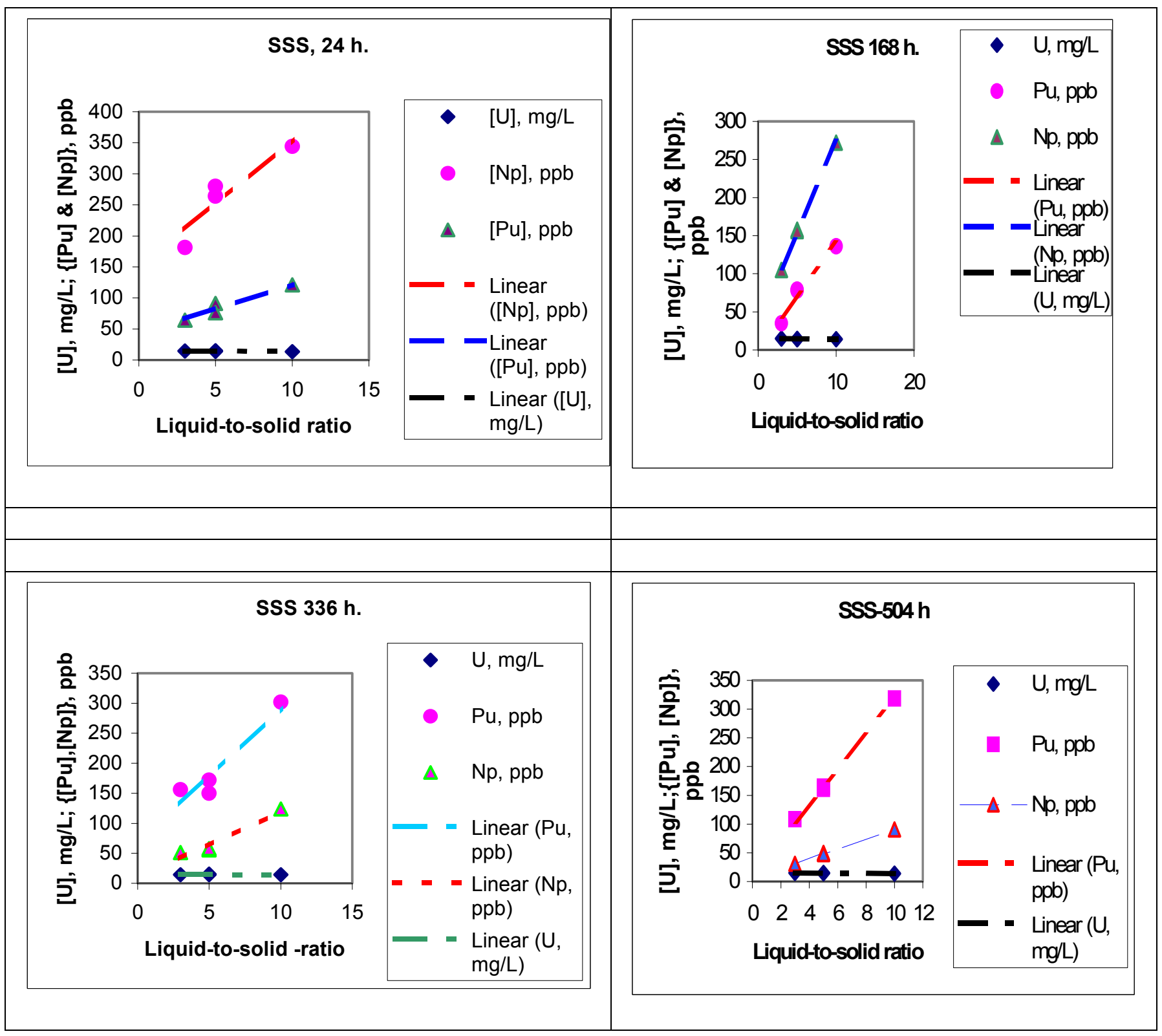


B2-24, 168, 336 and 504 hour-elapsed time data for SSS in contact with Tank 50H solids.

\begin{tabular}{|c|c|c|c|c|c|c|c|}
\hline L/S Ratio & [U], mg/L & {$[\mathrm{Np}], \mathrm{ppb}$} & {$[\mathrm{Pu}], \mathrm{ppb}$} & L/S Ratio & $\mathrm{U}, \mathrm{mg} / \mathrm{L}$ & $\mathrm{Pu}, \mathrm{ppb}$ & $\mathrm{Np}, \mathrm{ppb}$ \\
\hline 3 & & & 64.5 & 3 & 14.904 & & \\
\hline 5 & & & 91 & 5 & 14.422 & & \\
\hline 5 & & & 76 & 5 & 14.168 & & \\
\hline 10 & & & 121 & 10 & 13.998 & & \\
\hline 3 & & 181.5 & & 3 & & 35 & \\
\hline 5 & & 264 & & 5 & & 78 & \\
\hline 5 & & 280 & & 5 & & 79 & \\
\hline 10 & & 344 & & 10 & & 136 & \\
\hline 3 & 14.41 & & & 3 & & & 105 \\
\hline 5 & 14.15 & & & 5 & & & 158 \\
\hline 5 & 14.86 & & & 5 & & & 156 \\
\hline 10 & 13.67 & & & 10 & & & 272 \\
\hline Initial [conc] & 13.65 & 650 & 275 & Initial [conc] & 13.65 & 650 & 275 \\
\hline \multicolumn{4}{|c|}{24 hours } & \multicolumn{4}{|c|}{168 hours } \\
\hline L/S Ratio & $\mathrm{U}, \mathrm{mg} / \mathrm{L}$ & $\mathrm{Pu}, \mathrm{ppb}$ & $\mathrm{Np}, \mathrm{ppb}$ & L/S Ratio & $\mathrm{U}, \mathrm{mg} / \mathrm{L}$ & $\mathrm{Pu}, \mathrm{ppb}$ & $\mathrm{Np}, \mathrm{ppb}$ \\
\hline 3 & 14.533 & & & 3 & 14.86 & & \\
\hline 5 & 14.352 & & & 5 & 14.71 & & \\
\hline 5 & 15.174 & & & 5 & 14.62 & & \\
\hline 10 & 14.352 & & & 10 & 14 & & \\
\hline 3 & & 156 & & 3 & & 108.45 & \\
\hline 5 & & 150 & & 5 & & 161.12 & \\
\hline 5 & & 172 & & 5 & & 165.32 & \\
\hline 10 & & 302 & & 10 & & 318.4 & \\
\hline 3 & & & 51 & 3 & & & 30.99 \\
\hline 5 & & & 56 & 5 & & & 49.68 \\
\hline 5 & & & 58 & 5 & & & 47.8 \\
\hline 10 & & & 124 & 10 & & & 90.8 \\
\hline Initial [conc] & 13.65 & 650 & 275 & Initial [conc] & 13.65 & 650 & 275 \\
\hline
\end{tabular}


B3-24, 168, 336 and 504 hour-elapsed time overlay plots for DSS in contact with Tank 50H solids.

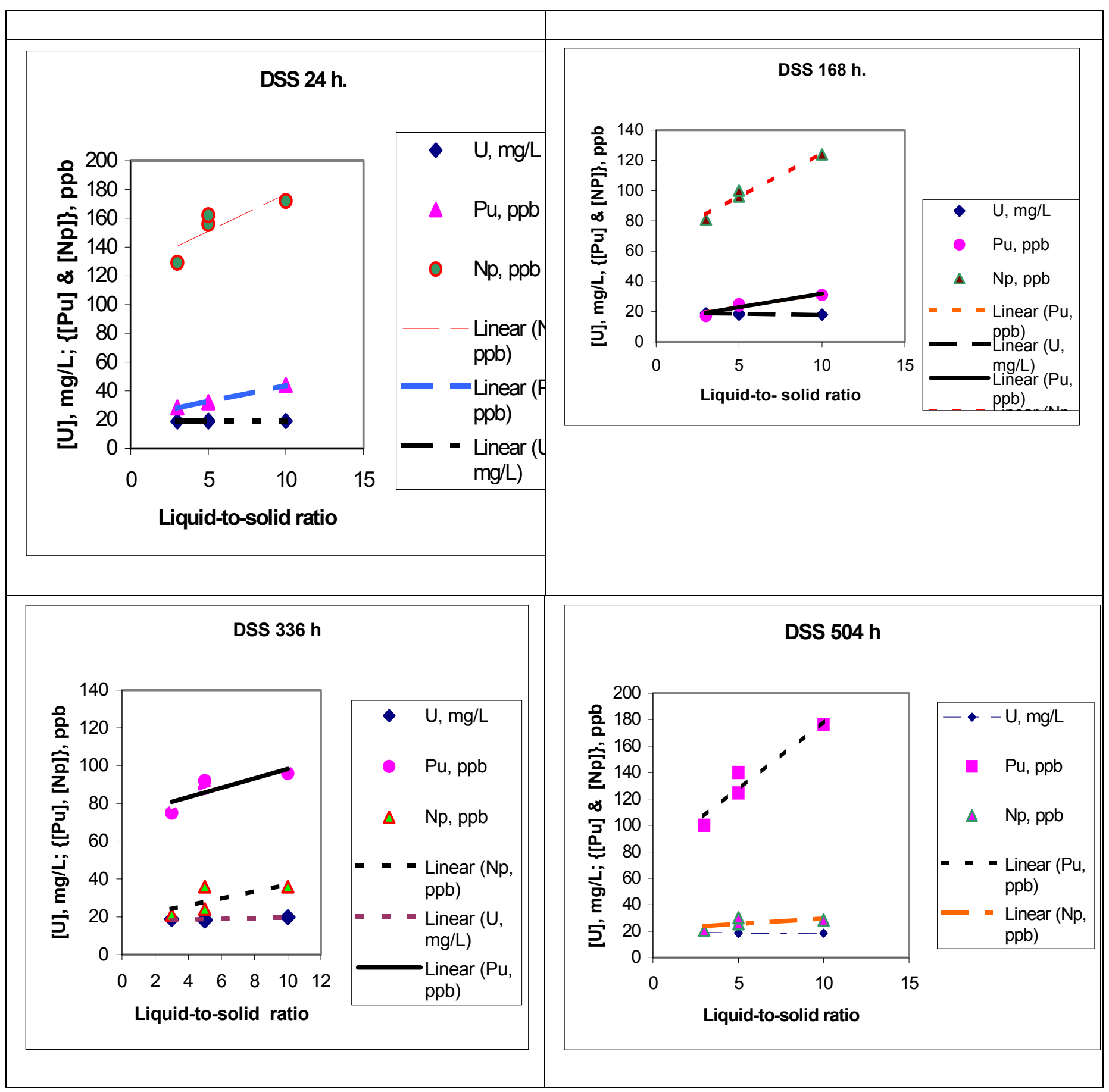


B4-24, 168, 336 and 504 hour-elapsed time data for DSS in contact with Tank 50H solids.

\begin{tabular}{|c|c|c|c|c|c|c|c|}
\hline L/S Ratio & $\mathrm{U}, \mathrm{mg} / \mathrm{L}$ & $\mathrm{Pu}, \mathrm{ppb}$ & $\mathrm{Np}, \mathrm{ppb}$ & L/S Ratio & $\mathrm{U}, \mathrm{mg} / \mathrm{L}$ & $\mathrm{Pu}, \mathrm{ppb}$ & $\mathrm{Np}, \mathrm{ppb}$ \\
\hline 3 & 18.81 & & & 3 & 18.897 & & \\
\hline 5 & 18.74 & & & 5 & 18.984 & & \\
\hline 5 & 19.3 & & & 5 & 18.08 & & \\
\hline 10 & 18.97 & & & 10 & 17.952 & & \\
\hline 3 & & 28.5 & & 3 & & 17 & \\
\hline 5 & & 32 & & 5 & & 25 & \\
\hline 5 & & 32 & & 5 & & 24 & \\
\hline 10 & & 44 & & 10 & & 31 & \\
\hline 3 & & & 129 & 3 & & & 81 \\
\hline 5 & & & 156 & 5 & & & 96 \\
\hline 5 & & & 162 & 5 & & & 100 \\
\hline 10 & & & 172 & 10 & & & 124 \\
\hline Initial [conc] & 19 & 52 & & Initial [conc] & 19 & 52 & \\
\hline \multicolumn{4}{|c|}{24 hours } & \multicolumn{4}{|c|}{168 hours } \\
\hline L/S Ratio & $\mathrm{U}, \mathrm{mg} / \mathrm{L}$ & $\mathrm{Pu}, \mathrm{ppb}$ & $\mathrm{Np}, \mathrm{ppb}$ & L/S Ratio & $\mathrm{U}, \mathrm{mg} / \mathrm{L}$ & $\mathrm{Pu}, \mathrm{ppb}$ & $\mathrm{Np}, \mathrm{ppb}$ \\
\hline 3 & 18.836 & & & 3 & 19.21 & & \\
\hline 5 & 18.076 & & & 5 & 18.96 & & \\
\hline 5 & 18.676 & & & 5 & 18.21 & & \\
\hline 10 & 19.845 & & & 10 & 18.58 & & \\
\hline 3 & & 75 & & 3 & & 100.11 & \\
\hline 5 & & 92 & & 5 & & 124.6 & \\
\hline 5 & & 88 & & 5 & & 140 & \\
\hline 10 & & $\begin{array}{c}96 \\
116\end{array}$ & & 10 & & 176.4 & \\
\hline 3 & & & 21 & 3 & & & 20.58 \\
\hline 5 & & & 24 & 5 & & & 25.6 \\
\hline 5 & & & 36 & 5 & & & 30.12 \\
\hline 10 & & & 36 & 10 & & & 28.48 \\
\hline Initial [conc] & 19 & & 56 & Initial [conc] & 19 & & 56 \\
\hline \multicolumn{4}{|c|}{336 hours } & \multicolumn{4}{|c|}{504 hours } \\
\hline
\end{tabular}




\subsection{REFERENCES}

i Banaszewski, C.D., "Engineering Path Forward HTF-PF-2002-0014: Tank 50H Solids (U)", HLW-STE-2002-00388, October 23,2002.

ii Banaszewski, C.D., "Tank 50 Solids Mound Volume Calculation", J-CLC-H-00793, Rev. 0, November 2002.

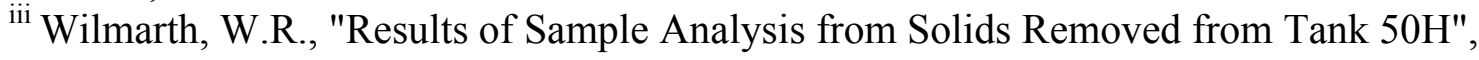
WSRC-TR-2002-00506, November 1,2002.

iv S. D. Fink, D. T. Hobbs, M. A. Norato, T. B. Peters and D. D. Walker, "Demonstration of MST and Permanganate Efficiency on Removal of Actinides and Strontium From Savannah River Site High Level Waste,” WSRC-TR-2002-00355, January 2003. 
This page intentionally left blank 